\title{
RECEIVED
}

DEC 272000

OSTI

\section{Status Report on Phase Identification in Hanford Tank Sludges}

\author{
B. M. Rapko \\ G. J. Lumetta \\ Radiochemical Processing Group \\ Pacific Northwest National Laboratory
}

December 2000

Prepared for the U.S. Department of Energy

under Contract DE-AC06-76RL0 1830

Pacific Northwest National Laboratory

Richland, Washington 99350 



\section{DISCLAIMER}

This report was prepared as an account of work sponsored by an agency of the United States Government. Neither the United States Government nor any agency thereof, nor any of their employees, make any warranty, express or implied, or assumes any legal liability or responsibility for the accuracy, completeness, or usefulness of any information, apparatus, product, or process disclosed, or represents that its use would not infringe privately owned rights. Reference herein to any specific commercial product, process, or service by trade name, trademark, manufacturer, or otherwise does not necessarily constitute or imply its endorsement, recommendation, or favoring by the United States Government or any agency thereof. The views and opinions of authors expressed herein do not necessarily state or reflect those of the United States Government or any agency thereof. 


\section{DISCLAIMER}

Portions of this document may be illegible in electronic image products. Images are produced from the best available original document. 


\section{Summary}

The U.S. Department of Energy plans to vitrify Hanford's tank wastes. The vitrified wastes will be divided into low-activity and high-level fractions. There is an effort to reduce the quantity of highactivity wastes by removing nonradioactive components because of the high costs involved in treating high-level waste. Pretreatment options, such as caustic leaching, to selectively remove nonradioactive components are being investigated. The effectiveness of these proposed processes for removing nonradioactive components depends on the chemical phases in the tank sludges. This review summarizes the chemical phases identified to date in Hanford tank sludges. 



\section{Glossary}

$\begin{array}{ll}\text { CC } & \text { complex concentrate } \\ \text { CW } & \text { cladding waste } \\ \text { DOE } & \text { U.S. Department of Energy } \\ \text { DIA } & \text { diatomaceous earth } \\ \text { DSSF } & \text { double-shell slurry feed } \\ \text { EB } & \text { evaporator bottoms } \\ \text { ED } & \text { electron diffraction } \\ \text { EDX } & \text { electron dispersive X-ray } \\ \text { ESPIP } & \text { Efficient Separations and Processing Integrated Program } \\ \text { ESW } & \text { enhanced sludge washing } \\ \text { F } & \text { ferrocyanide-scavenged waste } \\ \text { HLW } & \text { high-level waste } \\ \text { ICDD } & \text { International Centre for Diffraction Data } \\ \text { IHLW } & \text { immobilized high-level waste } \\ \text { ITS } & \text { in-tank solidification } \\ \text { LANL } & \text { Los Alamos National Laboratory } \\ \text { LAW } & \text { low-activity waste } \\ \text { NCAW } & \text { neutralized current acid waste } \\ \text { NCRW } & \text { neutralized cladding removal waste } \\ \text { OWW } & \text { organic solvent wash from the PUREX process } \\ \text { PNNL } & \text { Pacific Northwest National Laboratory } \\ \text { PUREX } & \text { plutonium-uranium extraction process } \\ \text { R } & \text { high-level REDOX waste } \\ \text { RED } & \text { reduction oxidation } \\ \text { strontium leached sludge }\end{array}$


SR-WASH particulates from Sr-wash of PUREX waste in the AR vault

TBP tributyl phosphate waste

TEM transmission electron microscopy

TFA Tanks Focus Area

TWRS Tank Waste Remediation System

USTID Underground Storage Tank Integrated Demonstration

XRD X-ray diffraction 


\section{Acknowledgements}

The authors (and colleagues) thank the U.S. Department of Energy Office of Science and Technology (Tanks Focus Area [TFA]), the Tank Waste Remediation System (TWRS), the Underground Storage Tank Integrated Demonstration (USTID), and the Efficient Separations and Processing Integrated Program (ESPIP) for supporting the phase-identification studies over the past several years. Pacific Northwest National Laboratory is operated by Battelle for the U.S. Department of Energy under Contract DE-AC06-76RLO 1830. 


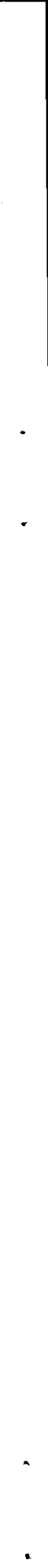




\section{Contents}

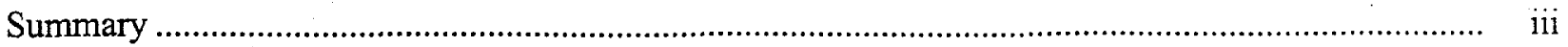

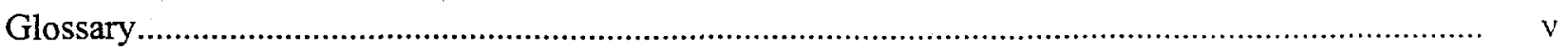

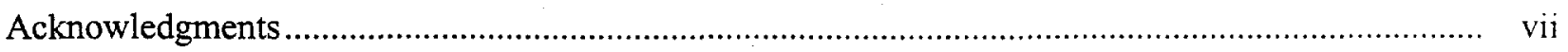

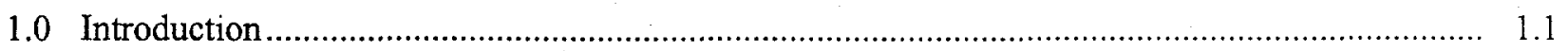

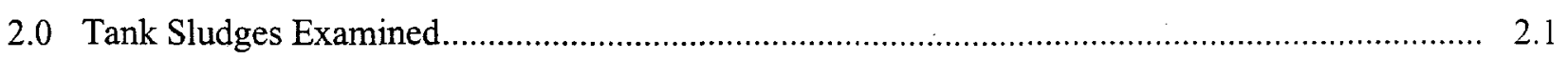

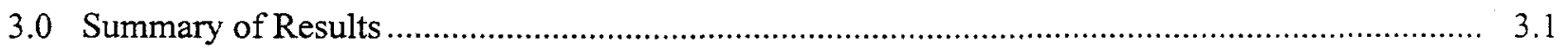

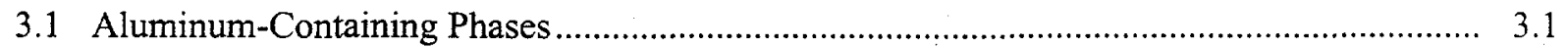

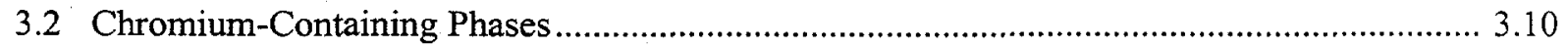

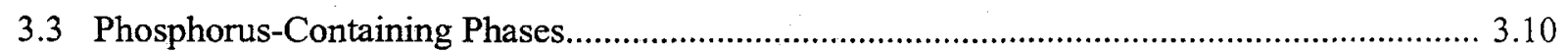

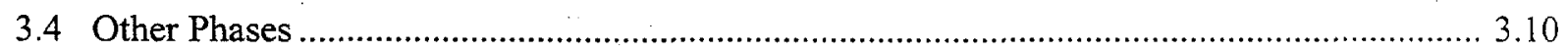

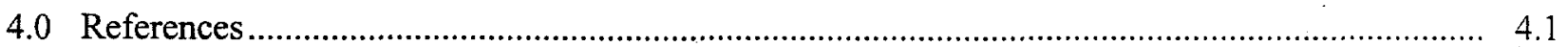

\section{Tables}

2.1 Summary of Hanford Tank Sludges Examined for Chemical Phase Information ......................... 2.3

3.1 Aluminum-Containing Phases Identified in Hanford Tank Sludges ....................................... 3.1

3.2 Chromium-Containing Phases Identified in Hanford Tank Sludges ......................................... 3.11

3.3 Phosphorus-Containing Phases Identified in Hanford Tank Sludges ........................................... 3.13

3.4. Other Phases Identified in Hanford Tank Sludges................................................................ 3.15 


\subsection{Introduction}

Large volumes of high-level radioactive wastes (HLWs), generated during past Pu production and other operations, are stored in underground tanks at the U.S. Department of Energy's (DOE's) Hanford Site in Washington State. Because of the expected high cost of HLW immobilization and geologic disposal, pretreatment processes will be implemented to reduce the volume of immobilized high-level waste (IHLW). After partitioning of the tank wastes into high-level and low-activity fractions, the currently envisioned pretreatment strategy proposes to 1) remove radionuclides from the aqueous waste fractions to produce streams suitable for disposal as low-activity waste (LAW) and 2) use washing and selective leaching strategies to remove elements from sludges expected to drive HLW production, i.e., aluminum, phosphorus, and chromium. The LAW will be immobilized in a glass matrix and disposed of by shallow burial onsite. The HLW will be immobilized in a borosilicate glass matrix; the resulting glass canisters will then be disposed of in a geologic repository (Orme et al. 1996).

Dilute hydroxide washing is the minimum pretreatment for Hanford tank sludges. This method simply involves mixing the sludge with dilute $(0.1 \underline{\mathrm{M}}$ or less) $\mathrm{NaOH}$ and then performing a solid/liquid separation. This is meant to remove water-soluble sludge components (mainly sodium salts) from the HLW stream. Dilute hydroxide is used rather than water to maintain the ionic strength high enough that colloidal suspensions are avoided.

The current baseline pretreatment for Hanford tank sludges involves an enhanced sludge washing (ESW) process. In this process, sludges will be leached with a more concentrated (typically $3 \mathrm{M}$ ) aqueous $\mathrm{NaOH}$ solution. The leached sludge will be subsequently washed with dilute $\mathrm{NaOH}$ to remove excess $\mathrm{Na}$ and any dissolved waste components. Leaching with $\mathrm{NaOH}$ is expected to remove a large fraction of the $\mathrm{Al}$, which is present in large quantities in Hanford tank sludges. The Al will be removed by converting aluminum oxides/hydroxides to sodium aluminate (Equations 1 and 2). The chemistry involved in this process is well known, as it forms the basis for the Bayer process in the aluminum industry (Weifers and Misra 1987).

$$
\begin{gathered}
\mathrm{Al}(\mathrm{OH})_{3}(\mathrm{~s})+\mathrm{NaOH}(\mathrm{aq}) \rightarrow \mathrm{NaAl}(\mathrm{OH})_{4}(\mathrm{aq}) \\
\mathrm{Al}(\mathrm{O})(\mathrm{OH})(\mathrm{s})+\mathrm{H}_{2} \mathrm{O}+\mathrm{NaOH}(\mathrm{aq}) \rightarrow \mathrm{NaAl}(\mathrm{OH})_{4}(\mathrm{aq})
\end{gathered}
$$

ESW is also expected to remove a significant portion of the $P$ from the sludge by metathesis of waterinsoluble metal phosphates to insoluble hydroxides and soluble $\mathrm{Na}_{3} \mathrm{PO}_{4}$. An example of this is shown for iron(III) phosphate in Equation 3.

$$
\mathrm{FePO}_{4}(\mathrm{~s})+3 \mathrm{NaOH}(\mathrm{aq}) \rightarrow \mathrm{Fe}(\mathrm{OH})_{3}(\mathrm{~s})+\mathrm{Na}_{3} \mathrm{PO}_{4}(\mathrm{aq})
$$

Similar metathesis reactions can occur for insoluble sulfate salts, allowing the removal of sulfate from the HLW stream. 
Based on its known amphoteric behavior (Rai et al. 1987), $\mathrm{Cr}$ (III) was expected to be removed by caustic leaching according to Equation 4:

$$
\mathrm{Cr}(\mathrm{OH})_{3}(\mathrm{~s})+\mathrm{NaOH}(\mathrm{aq}) \rightarrow \mathrm{Na}\left[\mathrm{Cr}(\mathrm{OH})_{4}\right](\mathrm{aq})
$$

However, we have observed that $\mathrm{Cr}$ in the caustic-leaching solutions is generally present as $\mathrm{Cr}(\mathrm{VI})$, suggesting that an oxidative pathway is involved (Lumetta et al. 1998).

The effectiveness of the proposed ESW process essentially depends on the chemical phases present in the tank sludges. For example, while aluminum in the form of hydroxide, oxides, or oxyhydroxides may be expected to dissolve to a significant extent, dissolution of aluminum in the form of aluminosilicates is problematic. Similarly, while phosphate in the form of iron or uranium phosphate should metathesize to metal hydroxides and soluble sodium phosphate according to Equation 3, metathesis of phosphate in the form of calcium phosphate is thermodynamically unfavorable. Because the specific chemical phases present can impact the effectiveness of pretreatment processes, efforts to identify the chemical phases present in a variety of Hanford tank sludges have been underway over the past several years. These efforts have combined powder X-ray diffraction (XRD), transmission electron microscopy/electron diffraction (TEM/ED), and scanning electron microscopy/electron dispersive X-ray (SEM/EDX) techniques to identify major phases present in Hanford tank sludges both before and after pretreatment processes. In this report, we summarize the results obtained through FY 1999. Aspects of this summary already have been reported (Lafemina 1995; Lumetta et al. 1998; Rapko et al. 1996). 


\subsection{Tank Sludges Examined}

Numerous sludge-type wastes have been examined over the years for phase information. Table 2.1 summarizes the Hanford tanks examined, the assigned grouping of each tank based on the history of waste types added (the Sort on Radioactive Waste Type model for single-shell tanks [Hill et. al 1995]), the specific type(s) of waste believed to be contained in the tank, and the original document(s) describing the phase analyses. All analyses were conducted on actual tank sludge waste. ${ }^{(a)}$ Samples typically were composites derived from core samples taken through risers in the top of the tanks. Specific experimental details used in preparing the caustic-leached samples are available in the cited references. Three types of analyses were performed to determine chemical phases. Powder XRD was used by Los Alamos National Laboratory (LANL) in all their studies and by Pacific Northwest National Laboratory (PNNL) in their initial studies. The other two analysis methods employed either TEM coupled with ED analysis or SEM coupled with EDX techniques.

At PNNL, the XRD analyses were performed using a Scintag Pad x-ray diffractometer. The $2 \theta$ range was 5 to 65 degrees with a counting time of $20 \mathrm{sec}$. X-ray tube conditions were 45 kilovolts and 40 milliamps. The copper $\mathrm{K} \alpha$ line was used for the measurement, and the instrument was operated in the $\theta / 2 \theta$ mode. At LANL, a Rigaku x-ray diffractometer/monochromator was used. In both instances, a computerized search/match routine of the International Centre for Diffraction Data (ICDD) data set \# 41 (PNNL) or \# 43 (LANL) was used to identify crystalline phases. A chemical filter was used to select the elements present in potential matches; the selected elements were determined from the SEM/EDX analysis.

The TEM samples were prepared by dispersing a drop of the sample slurry on TEM copper grids covered with carbon films. This work was performed using a JEOL 1200 analytical TEM operating at $120 \mathrm{kV}$. The analyses involved 1) evaluating the morphology, distribution, and particle sizes by electron imaging, 2) determining the particle's chemical composition by electron dispersive X-ray analysis, 3) studying the particle's crystallinity by electron diffraction, and 4) identifying the particle's crystalline phase by comparison with the JCPS-EDD Data Base published by the ICDD.

At PNNL, a JEOL JSM840 scanning electron microscope was used to perform the SEM/EDX analyses. Samples were attached to SEM mounts using double-sided sticky tape and were carbon coated before SEM examination. At LANL, these measurements were made with a JEOL 6300F X-Vision scanning electron microscope with a PGT IMIX imaging/x-ray microanalysis system.

The following review is organized by phases that contain major nonradioactive sludge components critical to the ESW process, e.g., Al-, $\mathrm{Cr}$-, and P-containing phases. Other identified phases also are discussed. In general, cases where microscopic examination revealed a particle's elemental composition, but where no phase information could be inferred, are not discussed. Some exceptions are made for

(a) It should be noted that "as-received" samples typically would have contained interstitial liquid. Water-soluble components (e.g., $\mathrm{NaNO}_{3}, \mathrm{NaNO}_{2}$, etc.) observed in the "as-received" samples likely formed during evaporation of the sample. 
simple systems where the phases present can be reasonably inferred, such as amorphous metal hydroxides or amorphous aluminosilicates. 
Table 2.1. Summary of Hanford Tank Sludges Examined for Chemical Phase Information

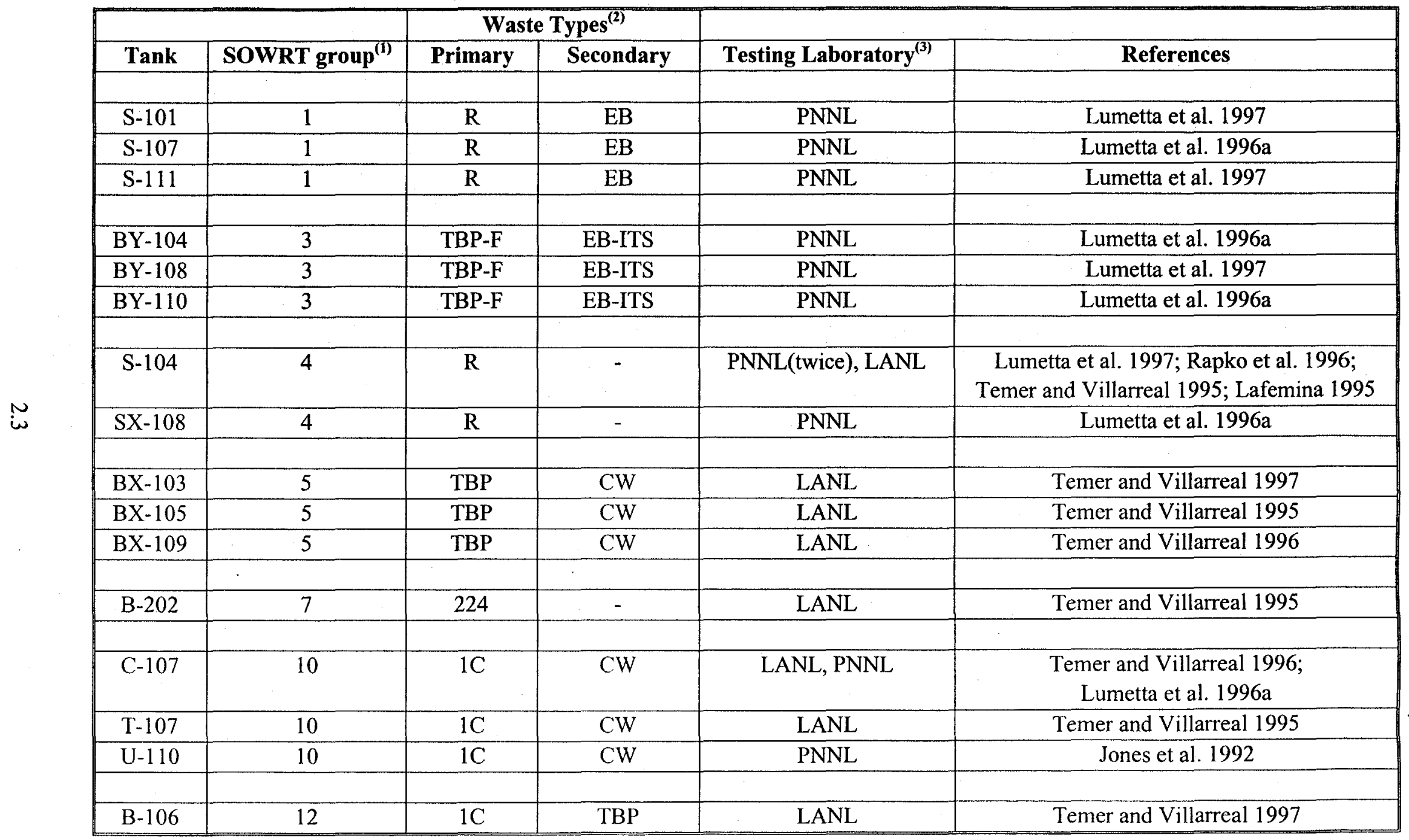


Table 2.1 (Continued)

\begin{tabular}{|c|c|c|c|c|c|}
\hline & & $\mathbf{W a}$ & $\operatorname{Types}^{(2)}$ & & \\
\hline Tank & SOWRT group ${ }^{(1)}$ & Primary & Secondary & Testing Laboratory $^{(3)}$ & References \\
\hline $\mathrm{BX}-107$ & 12 & 1C & TBP & PNNL & Rapko et al. 1996; Lafemina 1995 \\
\hline C-108 & 13 & TBP-F & $1 \mathrm{C}$ & LANL & Temer and Villarreal 1995 \\
\hline C-109 & 13 & TBP-F & $1 \mathrm{C}$ & PNNL & Colton et al. 1993 \\
\hline $\mathrm{C}-112$ & 13 & TBP-F & $1 \mathrm{C}$ & PNNL & Colton et al. 1993; Lafemina 1995 \\
\hline $\mathrm{B}-110$ & 16 & $2 \mathrm{C}$ & 56 & PNNL & Jones et al. 1992 \\
\hline B-111 & 16 & $2 \mathrm{C}$ & 56 & PNNL & Rapko et al. 1996; Lafemina 1995 \\
\hline C-106 & 20 & SRS & SR-WASH & PNNL & Lumetta et al. $1996 \mathrm{~b}$ \\
\hline $\mathrm{T}-104$ & Ungrouped & $1 \mathrm{C}$ & - & PNNL, LANL & Rapko et al. 1996; Lafemina 1995 \\
\hline $\mathrm{T}-111$ & 15 & $2 \mathrm{C}$ & 224 & PNNL & Rapko et al. 1996; Lafemina 1995 \\
\hline B-104 & Ungrouped & $2 \mathrm{C}$ & $\mathrm{EB}$ & LANL & Temer and Villarreal 1996 \\
\hline TY-104 & 22 & TBP & $1 \mathrm{C}-\mathrm{F}$ & LANL & Temer and Villarreal 1996 \\
\hline $\mathrm{SX}-113$ & 24 & $\mathrm{R}$ & DIA & LANL & Temer and Villarreal 1997 \\
\hline C-104 & Ungrouped & $\mathrm{CW}$ & OWW & LANL & Temer and Villarreal 1997 \\
\hline C-105 & Ungrouped & TBP & SR-WASH & LANL & Temer and Villarreal 1997 \\
\hline AN-104 & double shell tank & DSSF & - & PNNL & Lumetta et al. 1997 \\
\hline & & & & & \\
\hline
\end{tabular}


Table 2.1 (Continued)

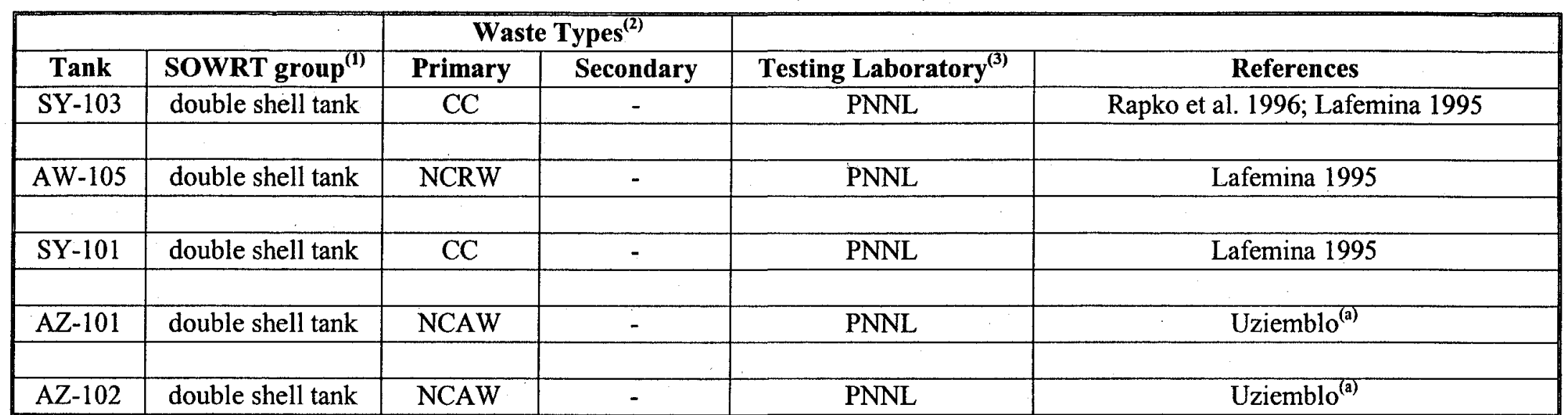

1. Assignments of groups of single-shell tanks based on a statistical

DIA $=$ Diatomaceous earth method (Hill et. al 1995).

2. For a fuller description of the waste types in single-shell tanks see Hill et. al (1995); for double-shell tanks see Hanlon (2000).

3. PNNL = Pacific Northwest National Laboratory; LANL $=$ Los

Alamos National Laboratory

$224=$ Lanthanum fluoride decontamination waste

$1 \mathrm{C}=$ First cycle bismuth phosphate decontamination waste

$2 \mathrm{C}=$ Second cycle bismuth phosphate decontamination waste

5-6 = High-level B Plant waste from the bottom of Section 5

$\mathrm{CC}=$ Complex concentrate

$\mathrm{CW}=$ Cladding waste

DSSF $=$ Double-shell slurry feed

$\mathrm{EB}=$ Evaporator bottoms

ITS $=$ In-tank solidification

$\mathrm{F}=$ Ferrocyanide-scavenged waste

NCAW $=$ Neutralized Current Acid Waste

NCRW $=$ Neutralized Cladding Removal Waste

OWW = Organic solvent wash from PUREX

$\mathrm{R}=$ High-level REDOX waste

SRS $=$ Strontium leached sludge

SR-WASH = Particulates from Sr-wash of PUREX waste in the AR vault

TBP $=$ Tributyl phosphate waste

(a) NH Unziemblo, B Mastel, and RR Adee. Unpublished results (1987). 


\subsection{Summary of Results}

\subsection{Aluminum-Containing Phases}

Table 3.1 summarizes the Al-containing phases that have been identified in the Hanford tank sludges. The species reported were identified either in the as-received sample or in material that has been subjected to caustic leaching (generally at $80^{\circ} \mathrm{C}-100^{\circ} \mathrm{C}$ for several hours with a leachate nominally $3 \mathrm{M}$ $\mathrm{NaOH}$ followed by dilute hydroxide washing to remove components in the interstitial liquid). Clearly, the sludges contain a variety of chemical species containing Al. For the sludges derived from the reduction oxidation (REDOX) process, boehmite is generally the dominant Al-containing species. Microscopic examinations also have revealed species such as $\mathrm{Al}(\mathrm{OH})_{3}$ (amorphous or crystalline), $\mathrm{Al}_{2} \mathrm{O}_{3} \bullet \times \mathrm{H}_{2} \mathrm{O}, \mathrm{AlPO}_{4}$, and both amorphous and crystalline aluminosilicates. It is unclear whether the frequency of aluminosilicates in the leached solids is due to their formation during the caustic-leaching process or to the effective removal of the other, more abundant, aluminum phases by the caustic-leaching process. The response of the phases identified in the as-received solids to caustic leaching has been summarized previously (Lumetta et al. 1998).

Not included in Table 3.1 is some early SEM/EDX work conducted on sludge from Hanford Tank SY-102 (Lumetta and Swanson 1993). This work is not included in the table because the solid phases present were not definitively identified. Nevertheless, in light of the work performed in more recent years, it is instructive to re-examine this earlier work. The water-washed SY-102 sludge consisted mostly of agglomerated particles. The EDS taken over a wide range of this material indicated the predominant elements present to be $\mathrm{Al}, \mathrm{Ca}, \mathrm{Cr}, \mathrm{Mn}$, and $\mathrm{Fe}$. The presence of $\mathrm{Th}$ was also evident. In addition to the agglomerated particles, distinct cubic-shaped particles were evident. The latter particles remained in the solid residue following acid dissolution. The EDX of these particles showed them to be Al-rich. The morphology of these particles was very similar to the morphology of the boehmite particles identified in the S-101 and S-104 sludges (Lumetta et al. 1998); thus, they were likely boehmite.

Table 3.1. Aluminum-Containing Phases Identified in Hanford Tank Sludges

\begin{tabular}{|c|c|c|c|}
\hline Tank & As-Received & Leached & Method \\
\hline S-101 & $\mathrm{Al}(\mathrm{O})(\mathrm{OH})($ boehmite) & $\begin{array}{l}\mathrm{Al}(\mathrm{O})(\mathrm{OH})(\text { boehmite) } \\
\text { aluminosilicates (am), } \\
\mathrm{Al}(\mathrm{O})(\mathrm{OH})(\text { diaspore })\end{array}$ & TEM \\
\hline S-107 & $\begin{array}{l}\mathrm{Al}(\mathrm{O})(\mathrm{OH})(\text { boehmite}) \\
\text { aluminosilicates }(\mathrm{am})\end{array}$ & $\begin{array}{l}\mathrm{Al}(\mathrm{O})(\mathrm{OH}) \text { (boehmite), } \\
\text { aluminosilicates (am) }\end{array}$ & TEM \\
\hline S-111 & NP & $\begin{array}{c}\mathrm{Al}(\mathrm{OH})_{3} \text { (bayerite) } \\
\mathrm{Al}(\mathrm{O})(\mathrm{OH}) \text { (boehmite) }\end{array}$ & TEM \\
\hline BY-104 & $\begin{array}{c}\left(\mathrm{Al}_{2} \mathrm{O}_{3}\right)_{\mathrm{x}}-\left(\mathrm{H}_{2} \mathrm{O}\right)_{\mathrm{y}} \\
\text { aluminosilicates }(\mathrm{am})\end{array}$ & $\left(\mathrm{Al}_{2} \mathrm{O}_{3}\right)_{\mathrm{x}}-\left(\mathrm{H}_{2} \mathrm{O}\right)_{\mathrm{y}}$ & TEM \\
\hline
\end{tabular}


Table 3.1 (continued)

\begin{tabular}{|c|c|c|c|}
\hline Tank & As-Received & Leached & Method \\
\hline BY-108 & none & none & TEM \\
\hline BY-110 & NP & none & TEM \\
\hline S-104 & $\mathrm{Al}(\mathrm{O})(\mathrm{OH})$ (boehmite) & $\begin{array}{l}\mathrm{Al}(\mathrm{O})(\mathrm{OH}) \text { (boehmite), } \\
\text { aluminosilicate }(\mathrm{am})\end{array}$ & $\begin{array}{l}\text { TEM/SEM/ } \\
\text { XRD }\end{array}$ \\
\hline SX-108 & $\begin{array}{l}\mathrm{Al}(\mathrm{O})(\mathrm{OH})(\text { boehmite }) \\
\text { aluminosilicate }(\mathrm{a}) \\
\left(\mathrm{Al}_{2} \mathrm{O}_{3}\right)_{\mathrm{x}}-\left(\mathrm{H}_{2} \mathrm{O}\right)_{\mathrm{y}}\end{array}$ & $\begin{array}{c}\mathrm{Al}(\mathrm{O})(\mathrm{OH})(\text { boehmite }) \\
\text { aluminosilicate }(\mathrm{am}) \\
\left(\mathrm{Al}_{2} \mathrm{O}_{3}\right)_{\mathrm{x}}-\left(\mathrm{H}_{2} \mathrm{O}\right)_{\mathrm{y}} \\
\mathrm{Ca}_{3} \mathrm{Al}_{2} \mathrm{O}_{6}\end{array}$ & TEM \\
\hline BX-103 & $\mathrm{Al}(\mathrm{OH})_{3}$ (gibbsite) & none & $\mathrm{XRD}$ \\
\hline $\mathrm{BX}-105$ & $\mathrm{Al}(\mathrm{OH})_{3}$ (gibbsite) & $\mathrm{Al}(\mathrm{OH})_{3}$ (gibbsite) & XRD \\
\hline BX-109 & $\mathrm{Al}(\mathrm{OH})_{3}$ (nordstrandite) & none & $\mathrm{XRD}$ \\
\hline B-202 & none & $\mathrm{NP}$ & $\mathrm{XRD}$ \\
\hline C-107 & $\begin{array}{c}\text { none, } \\
\left(\mathrm{Al}_{2} \mathrm{O}_{3}\right)_{\mathrm{x}}-\left(\mathrm{H}_{2} \mathrm{O}\right)_{\mathrm{y}}, \\
\text { aluminosilicates }(\mathrm{am})\end{array}$ & $\begin{array}{c}\text { none, } \\
\left(\mathrm{Al}_{2} \mathrm{O}_{3}\right)_{\mathrm{x}}-\left(\mathrm{H}_{2} \mathrm{O}\right)_{\mathrm{y}} \\
\text { aluminosilicates }(\mathrm{am})\end{array}$ & XRD, TEM \\
\hline $\mathrm{T}-107$ & $\mathrm{Al}(\mathrm{OH})_{3}$ (gibbsite) & aluminosilicates (c), $\mathrm{Al}\left(\mathrm{PO}_{4}\right)$ & $\mathrm{XRD}$ \\
\hline U-110 & $\begin{array}{c}\mathrm{Al}(\mathrm{OH})_{3} \text { (gibbsite), } \\
\mathrm{Al}(\mathrm{O})(\mathrm{OH}) \text { (boehmite) }\end{array}$ & $\mathrm{NP}$ & SEM/XRD \\
\hline B-106 & none & none & $\mathrm{XRD}$ \\
\hline BX-107 & $\begin{array}{c}\mathrm{AlPO}_{4} \\
\mathrm{Al}(\mathrm{OH})_{3}(\mathrm{am}), \\
\text { aluminosilicates }(\mathrm{c}, \mathrm{am})\end{array}$ & aluminosilicates (c,am) & $\begin{array}{l}\text { TEM/SEM/ } \\
\text { XRD }\end{array}$ \\
\hline C-108 & $\mathrm{Al}(\mathrm{OH})_{3}$ (gibbsite) & none & $\mathrm{XRD}$ \\
\hline C-109 & $\mathrm{Al}(\mathrm{OH})_{3}$ (gibbsite) & $\begin{array}{c}\mathrm{Al}(\mathrm{OH})_{3} \text { (gibbsite), } \\
\mathrm{Al}(\mathrm{O})(\mathrm{OH}) \text { (boehmite), } \\
\text { Nickel Aluminum Oxide }\end{array}$ & SEM/XRD \\
\hline $\mathrm{C}-112$ & $\mathrm{Al}(\mathrm{OH})_{3}$ (gibbsite) & none & SEM/XRD \\
\hline B-110 & $\begin{array}{c}\text { Sodium Aluminum Silicate } \\
\text { Hydrate }\end{array}$ & $\mathrm{NP}$ & SEM/XRD \\
\hline B-111 & aluminosilicates (c) & aluminosilicates (c) & $\begin{array}{c}\text { TEM/SEM/ } \\
\mathrm{XRD} \\
\end{array}$ \\
\hline C-106 & $\begin{array}{c}\mathrm{Al}(\mathrm{OH})_{3}(\mathrm{am}), \\
\text { aluminosilicates }(\mathrm{am})\end{array}$ & aluminosilicates (am) & TEM \\
\hline
\end{tabular}


Table 3.1 (continued)

\begin{tabular}{|c|c|c|c|}
\hline Tank & As-Received & Leached & Method \\
\hline $\mathrm{T}-104$ & $\begin{array}{c}\mathrm{AlPO}_{4}, \\
\mathrm{Al}(\mathrm{OH})_{3}(\mathrm{am}), \\
\text { aluminosilicates }(\mathrm{c}, \mathrm{am}), \\
\mathrm{Na}_{2} \mathrm{Fe}_{2} \mathrm{Al}\left(\mathrm{PO}_{4}\right)_{3}\end{array}$ & $\begin{array}{c}\text { aluminosilicates (c,am), } \\
\qquad \mathrm{Bi}_{24} \mathrm{Al}_{2} \mathrm{O}_{39}\end{array}$ & $\begin{array}{l}\text { TEM/SEM/ } \\
\text { XRD }\end{array}$ \\
\hline $\mathrm{T}-111$ & none & none & $\begin{array}{l}\text { TEM/SEM/ } \\
\text { XRD }\end{array}$ \\
\hline B-104 & none & none & XRD \\
\hline TY-104 & none & none & $\mathrm{XRD}$ \\
\hline SX-113 & none & none & $\mathrm{XRD}$ \\
\hline C-104 & none & none & $\mathrm{XRD}$ \\
\hline $\mathrm{C}-105$ & $\mathrm{Al}(\mathrm{OH})_{3}$ (gibbsite) & none & XRD \\
\hline AN-104 & aluminosilicate (am) & none & TEM \\
\hline SY-103 & $\begin{array}{c}\mathrm{Al}(\mathrm{OH})_{3}(\mathrm{am}) \\
\mathrm{Al}_{2} \mathrm{O}_{3}\left(\mathrm{H}_{2} \mathrm{O}\right)_{x}(\mathrm{c})\end{array}$ & $\begin{array}{c}\mathrm{Al}(\mathrm{OH})_{3}(\mathrm{am}) \\
\mathrm{Al}_{2} \mathrm{O}_{3}\left(\mathrm{H}_{2} \mathrm{O}\right)_{\mathrm{x}}(\mathrm{c})\end{array}$ & $\begin{array}{c}\text { TEM/SEM/ } \\
\text { XRD } \\
\end{array}$ \\
\hline $\mathrm{AW}-105$ & $\begin{array}{c}\mathrm{Al}(\mathrm{OH})_{3}, \\
\text { aluminosilicate (c) }\end{array}$ & aluminosilicate (c) & $\begin{array}{c}\text { TEM/SEM/ } \\
\text { XRD }\end{array}$ \\
\hline SY-101 & $\mathrm{NaAlO}_{2}, \mathrm{Al}(\mathrm{OH})_{3}(\mathrm{am})$ & none & $\begin{array}{l}\text { TEM/SEM/ } \\
\text { XRD }\end{array}$ \\
\hline $\mathrm{AZ}-101$ & none & NP & SEM \\
\hline $\mathrm{AZ}-102$ & Aluminosilicate (am) & NP & SEM \\
\hline
\end{tabular}

$\mathrm{NP}=$ measurement not performed, am = amorphous, $\mathrm{c}=$ crystalline 


\subsection{Chromium-Containing Phases}

Table 3.2 summarizes the Cr-containing phases that have been identified in the Hanford tank sludges. Leaching conditions are the same as those described for Table 3.1. Few phases have been identified, especially in the untreated solids, which is presumably due to their generally low concentrations in the asreceived sludges. In the high-Cr sludge SY-103, the chromium seems to be present as an amorphous hydroxide. In another case, the $\mathrm{Cr}$ was found to be present as a crystalline oxyhydroxide, gramaldite. But in most of these infrequent cases, the identified Cr phase has the chromium bound up with other transition metals in spinel-type structures or, in the high $\mathrm{Bi}$-containing solids, in the compound $\mathrm{Bi}_{38} \mathrm{CrO}_{60}$. The response of the phases identified in the as-received solids to caustic leaching has been summarized previously (Lumetta et al. 1998).

\subsection{Phosphorus-Containing Phases}

Microscopy studies have revealed several P-containing species in the Hanford sludges (Table 3.3). For Table 3.3, the leaching conditions are the same as those described for Table 3.1. In general, these materials are present as simple metal phosphate salts. However, in T-111, phosphorus was determined to be present as the pyrophosphate in lanthanum pyrophosphate. The response of the phases identified in the as-received solids to caustic leaching has been summarized previously

(Lumetta et al. 1998).

\subsection{Other Phases}

Microscopy studies have revealed several other species in the Hanford sludges (Table 3.4). Again, for Table 3.4, the leaching conditions are the same as those described for Table 3.1. Most of the materials identified in the as-received sludges are either simple salts (such as sodium nitrate), the metal oxides or oxyhydroxides of such common elements as iron, silicon, or bismuth (for the high Bi-containing tanks), and, in several cases, uranium oxide, either as the $\mathrm{U}_{2} \mathrm{O}_{7}{ }^{2-}$ salt, or as an oxide compound such as $\mathrm{UO}_{3}, \mathrm{UO}_{2}$, or $\mathrm{U}_{3} \mathrm{O}_{7}$. The leached solids differ primarily by the disappearance of the simple sodium salts such as nitrate and nitrite and, often, the identification of other metal oxide phases. It is likely that these new phases were present even in the initial solids, but that the other, more abundant, material obscured their presence. 
Table 3.2. Chromium-Containing Phases Identified in Hanford Tank Sludges

\begin{tabular}{|c|c|c|c|}
\hline Tank & As-Received & Leached & Method \\
\hline S-101 & none & none & TEM \\
\hline S-107 & none & none & TEM \\
\hline $\mathrm{S}-111$ & NP & $\begin{array}{c}\mathrm{FeCr}_{2} \mathrm{O}_{4} \\
\mathrm{Mn}_{2} \mathrm{CrO}_{4} \\
\mathrm{Mn}_{1.5} \mathrm{Cr}_{1.5} \mathrm{O}_{4}\end{array}$ & TEM \\
\hline BY-104 & $\mathrm{Fe}(\mathrm{Fe}, \mathrm{Cr})_{2} \mathrm{O}_{4}$ (donathite) & none & TEM \\
\hline BY-108 & none & none & TEM \\
\hline $\mathrm{BY}-110$ & NP & $\mathrm{Cr}(\mathrm{O})(\mathrm{OH})$ (grimaldite) & TEM \\
\hline S-104 & none & none & TEM/SEM/XRD \\
\hline SX-108 & none & none & TEM \\
\hline BX-103 & none & none & XRD \\
\hline $\mathrm{BX}-105$ & none & none & $\mathrm{XRD}$ \\
\hline BX-109 & none & none & $\mathrm{XRD}$ \\
\hline B-202 & none & $\mathrm{NP}$ & $\mathrm{XRD}$ \\
\hline C-107 & none & none & XRD, TEM \\
\hline $\mathrm{T}-107$ & none & none & $\mathrm{XRD}$ \\
\hline $\mathrm{U}-110$ & none & NP & SEM/XRD \\
\hline B-106 & none & none & XRD \\
\hline BX-107 & none & none & TEM/SEM/XRD \\
\hline C-108 & none & none & $\mathrm{XRD}$ \\
\hline C-109 & none & none & SEM/XRD \\
\hline $\mathrm{C}-112$ & none & none & $\mathrm{SEM} / \mathrm{XRD}$ \\
\hline $\mathrm{B}-110$ & none & $\mathrm{NP}$ & SEM/XRD \\
\hline B-111 & $\mathrm{Bi}_{38} \mathrm{CrO}_{60}$ & $\mathrm{Bi}_{38} \mathrm{CrO}_{60}$ & TEM/SEM/XRD \\
\hline C-106 & none & none & TEM \\
\hline $\mathrm{T}-104$ & none & $\begin{array}{l}\mathrm{Bi}_{38} \mathrm{CrO}_{60} \\
\text { chromium phosphate }\end{array}$ & $\mathrm{TEM} / \mathrm{SEM} / \mathrm{XRD}$ \\
\hline & & & \\
\hline
\end{tabular}


Table 3.2 (Continued)

\begin{tabular}{|c|c|c|c|}
\hline Tank & As-Received & Leached & Method \\
\hline $\mathrm{T}-111$ & none & none & TEM/SEM/XRD \\
\hline B-104 & none & none & XRD \\
\hline TY-104 & none & none & $\mathrm{XRD}$ \\
\hline SX-113 & none & none & XRD \\
\hline C-104 & none & none & XRD \\
\hline & & $\cdot$ & \\
\hline $\mathrm{C}-105$ & none (XRD) & none & $\mathrm{XRD}$ \\
\hline AN-104 & none & none & TEM \\
\hline SY-103 & $\mathrm{Cr}(\mathrm{OH})_{3}(\mathrm{am})$ & $\mathrm{Cr}(\mathrm{OH})_{3}(\mathrm{am})$ & TEM/SEM/XRD \\
\hline AW-105 & none & none & TEM/SEM/XRD \\
\hline SY-101 & none & none & TEM/SEM/XRD \\
\hline AZ-101 & none & $\mathrm{NP}$ & SEM \\
\hline AZ-102 & none & $\overline{N P}$ & SEM \\
\hline
\end{tabular}

$\mathrm{NP}=$ measurement not performed, am = amorphous, $\mathrm{c}=$ crystalline 
Table 3.3. Phosphorus-Containing Phases Identified in Hanford Tank Sludges

\begin{tabular}{|c|c|c|c|}
\hline Tank & As-Received & Leached & Method \\
\hline S-101 & none & none & TEM \\
\hline S-107 & none & none & $\overline{\text { TEM }}$ \\
\hline S-111 & $\mathrm{NP}$ & none & TEM \\
\hline BY-104 & none & $\mathrm{Ca}_{5}(\mathrm{OH})\left(\mathrm{PO}_{4}\right)_{3}$ & TEM \\
\hline BY -108 & $\mathrm{Ca}_{\mathrm{x}} \mathrm{Sr}_{10-\mathrm{x}}\left(\mathrm{PO}_{4}\right)_{6}(\mathrm{OH})_{2}$ & $\mathrm{Ca}_{\mathrm{x}} \mathrm{Sr}_{10-\mathrm{x}}\left(\mathrm{PO}_{4}\right)_{6}(\mathrm{OH})_{2}$ & TEM \\
\hline BY -110 & NP & $\mathrm{Ca}_{5}(\mathrm{OH})\left(\mathrm{PO}_{4}\right)_{3}$ & TEM \\
\hline S-104 & none & none & TEM/SEM/XRD \\
\hline SX-108 & none & none & TEM \\
\hline BX-103 & none & $\overline{\text { none }}$ & $\mathrm{XRD}$ \\
\hline BX-105 & none & none & $\mathrm{XRD}$ \\
\hline BX-109 & none & none & $\mathrm{XRD}$ \\
\hline B-202 & none & NP & XRD \\
\hline & & & \\
\hline C-107 & $\begin{array}{c}\text { none }(\mathrm{XRD}) \\
\mathrm{Pb}_{5}(\mathrm{OH})\left(\mathrm{PO}_{4}\right)_{3}\end{array}$ & $\begin{array}{l}\text { none }(\mathrm{XRD}) \\
\text { none }\end{array}$ & XRD, TEM \\
\hline $\mathrm{T}-107$ & none & $\mathrm{Al}\left(\mathrm{PO}_{4}\right)$ & $\mathrm{XRD}$ \\
\hline $\mathrm{U}-110$ & none & NP & SEM/XRD \\
\hline B-106 & none & none & XRD \\
\hline $\mathrm{BX}-107$ & $\begin{array}{c}\mathrm{AlPO}_{4} \\
\mathrm{Bi} / \mathrm{FePO}_{4}\end{array}$ & $\mathrm{Bi} / \mathrm{FePO}_{4}$ & TEM/SEM/XRD \\
\hline C-108 & $\mathrm{Ca}_{3}\left(\mathrm{PO}_{4}\right)_{2}$ & $\begin{array}{c}\mathrm{Ca}_{5}(\mathrm{OH})\left(\mathrm{PO}_{4}\right)_{3} \\
\mathrm{Ca}_{5} \mathrm{~F}\left(\mathrm{PO}_{4}\right)_{3}\end{array}$ & XRD \\
\hline $\mathrm{C}-109$ & none & none & SEM/XRD \\
\hline $\mathrm{C}-112$ & none & none & SEM/XRD \\
\hline B-110 & $\widehat{\mathrm{BiPO}_{4}}$ & NP & SEM/XRD \\
\hline B-111 & $\mathrm{Na}_{3} \mathrm{PO}_{4}$ & $\mathrm{Na}_{3} \mathrm{PO}_{4}$ & TEM/SEM/XRD \\
\hline$C-106$ & none & none & TEM \\
\hline & & & \\
\hline$T-104$ & $\begin{array}{c}\mathrm{AlPO}_{4} \\
\mathrm{Na}_{2} \mathrm{Fe}_{2} \mathrm{Al}\left(\mathrm{PO}_{4}\right)_{3}(\mathrm{XRD})\end{array}$ & $\begin{array}{l}\text { chromium phosphate, } \\
\text { uranyl phosphate hydrate }\end{array}$ & TEM/SEM/XRD \\
\hline
\end{tabular}


Table 3.3 (continued)

\begin{tabular}{|c|c|c|c|}
\hline Tank & As-Received & Leached & Method \\
\hline $\mathrm{T}-111$ & $\begin{array}{c}\mathrm{Na}_{3} \mathrm{PO}_{4} \\
\mathrm{La}_{4}\left(\mathrm{P}_{2} \mathrm{O}_{7}\right)_{3} \\
\mathrm{Ca}_{5}(\mathrm{OH})\left(\mathrm{PO}_{4}\right)_{3} \\
\mathrm{Bi}, \mathrm{Fe} \text { phosphate }\end{array}$ & $\begin{array}{c}\mathrm{Ca}_{5}(\mathrm{OH})\left(\mathrm{PO}_{4}\right)_{3} \\
\mathrm{La}_{4}\left(\mathrm{P}_{2} \mathrm{O}_{7}\right)_{3} \\
\mathrm{Bi}, \text { Fe phosphate }\end{array}$ & TEM/SEM/XRD \\
\hline B-104 & none & none & XRD \\
\hline TY-104 & none & none & XRD \\
\hline $\mathrm{SX}-113$ & none & none & XRD \\
\hline C-104 & none & none & XRD \\
\hline C-105 & none & none & XRD \\
\hline AN-104 & none & none & TEM \\
\hline SY -103 & none & none & TEM/SEM/XRD \\
\hline $\mathrm{AW}-105$ & none & none & TEM/SEM/XRD \\
\hline & & & \\
\hline SY-101 & none & none & TEM/SEM/XRD \\
\hline AZ-101 & none & NP & SEM \\
\hline $\mathrm{AZ}-102$ & none & NP & SEM \\
\hline
\end{tabular}

$\mathrm{NP}=$ measurement not performed, $\mathrm{m}=$ amorphous, $\mathrm{c}=$ crystalline 
Table 3.4. Other Phases Identified in Hanford Tank Sludges

\begin{tabular}{|c|c|c|c|}
\hline Tank & As-Received & Leached & Method \\
\hline S-101 & $\mathrm{Mn} / \mathrm{Fe}(\mathrm{O})(\mathrm{OH})$ & $\mathrm{Mn} / \mathrm{Fe}(\mathrm{O})(\mathrm{OH})$ & $\overline{\text { TEM }}$ \\
\hline S-107 & $\begin{array}{c}\mathrm{ZrO}_{2} \\
\mathrm{Fe}(\mathrm{O})(\mathrm{OH}) \\
\mathrm{UO}_{3}\end{array}$ & $\begin{array}{c}\mathrm{ZrO}_{2} \\
\mathrm{Fe}(\mathrm{O})(\mathrm{OH}) \\
\mathrm{UO}_{3} \\
\end{array}$ & TEM \\
\hline S-111 & $\mathrm{NP}$ & $\mathrm{UO}_{3}$ & TEM \\
\hline BY-104 & none & $\begin{array}{c}\beta-\mathrm{U}_{3} \mathrm{O}_{8} \\
\mathrm{Ni}_{3} \mathrm{O}_{2}(\mathrm{OH})_{4} \\
\mathrm{Fe}(\mathrm{O})(\mathrm{OH})\end{array}$ & TEM \\
\hline BY-108 & $\begin{array}{c}\beta-\mathrm{U}_{3} \mathrm{O}_{8} \\
\gamma-\mathrm{Fe}_{2} \mathrm{O}_{3} \text { (maghemite) } \\
\mathrm{Fe}(\mathrm{O})(\mathrm{OH})\end{array}$ & $\begin{array}{c}\beta-\mathrm{U}_{3} \mathrm{O}_{8} \\
\gamma-\mathrm{Fe}_{2} \mathrm{O}_{3}(\text { maghemite }) \\
\mathrm{Fe}(\mathrm{O})(\mathrm{OH})\end{array}$ & TEM \\
\hline BY-110 & $\mathrm{NP}$ & $\begin{array}{c}\beta-\mathrm{U}_{3} \mathrm{O}_{8} \\
\mathrm{Ni}_{3} \mathrm{O}_{2}(\mathrm{OH})_{4} \\
\gamma-\mathrm{Fe}_{2} \mathrm{O}_{3} \text { (maghemite) }\end{array}$ & TEM \\
\hline S-104 & $\begin{array}{c}\beta-\mathrm{U}_{3} \mathrm{O}_{8} \\
\mathrm{NaNO}_{3} \text { (natratine) }\end{array}$ & $\begin{array}{l}\mathrm{UO}_{3}-2 \mathrm{H}_{2} \mathrm{O} \\
\mathrm{FeMnO}_{4}\end{array}$ & TEM/SEM/XRD \\
\hline SX-108 & $\begin{array}{c}\beta-\mathrm{U}_{3} \mathrm{O}_{8} \\
\mathrm{Fe}(\mathrm{O})(\mathrm{OH})\end{array}$ & $\begin{array}{c}\beta-\mathrm{U}_{3} \mathrm{O}_{8} \\
\mathrm{Fe}(\mathrm{O})(\mathrm{OH}) \\
(\mathrm{Mn}, \mathrm{Fe})_{3} \mathrm{O}_{4} \\
\end{array}$ & TEM \\
\hline $\mathrm{BX}-103$ & none & $\mathrm{Na}_{2} \mathrm{U}_{2} \mathrm{O}_{7}$ & $\mathrm{XRD}$ \\
\hline $\mathrm{BX}-105$ & none & none & XRD \\
\hline BX-109 & $\mathrm{NaNO}_{3}$ (natratine) & $\mathrm{Na}_{2} \mathrm{U}_{2} \mathrm{O}_{7}$ & XRD \\
\hline B-202 & $\mathrm{NaNO}_{3}$ (natratine) & NP & XRD \\
\hline C-107 & $\begin{array}{c}\mathrm{Fe}_{3} \mathrm{O}_{4} \text { (hematite) (XRD) } \\
\mathrm{Fe}(\mathrm{O})(\mathrm{OH}) \\
\mathrm{ZrO}_{2}\end{array}$ & $\begin{array}{c}\mathrm{Fe}_{3} \mathrm{O}_{4} \text { (hematite) (XRD) } \\
\mathrm{Fe}(\mathrm{O})(\mathrm{OH})\end{array}$ & XRD, TEM \\
\hline$T-107$ & $\mathrm{NaNO}_{3}$ (natratine) & none & XRD \\
\hline $\mathrm{U}-110$ & $\mathrm{NaNO}_{3}$ & $\mathrm{NP}$ & SEM/XRD \\
\hline B-106 & none & none & $\overline{\mathrm{XRD}}$ \\
\hline BX-107 & $\begin{array}{c}\mathrm{Fe}_{2} \mathrm{Bi}\left(\mathrm{SiO}_{4}\right)_{2}(\mathrm{OH}) \\
\mathrm{Bi}_{2} \mathrm{O}_{3} \\
\end{array}$ & $\begin{array}{c}\mathrm{Fe}_{2} \mathrm{Bi}\left(\mathrm{SiO}_{4}\right)_{2}(\mathrm{OH}) \\
\mathrm{Bi}_{2} \mathrm{O}_{3} \\
\end{array}$ & TEM/SEM/XRD \\
\hline
\end{tabular}


Table 3.4 (continued)

\begin{tabular}{|c|c|c|c|}
\hline Tank & As-Received & Leached & Method \\
\hline C-108 & $\mathrm{NaNO}_{3}$ (natratine) & none & XRD \\
\hline C-109 & $\begin{array}{c}\mathrm{NaNO}_{3} \\
\mathrm{NaNO}_{2} \\
\mathrm{SiO}_{2} \\
\end{array}$ & $\begin{array}{c}\mathrm{Ni}(\mathrm{OH})_{2} \\
\mathrm{UO}_{3}\end{array}$ & SEM/XRD \\
\hline C-112 & $\begin{array}{c}\mathrm{NaNO}_{3} \\
\mathrm{NaNO}_{2} \\
\mathrm{SiO}_{2} \\
\mathrm{CaU}_{2} \mathrm{O}_{7} \\
\end{array}$ & $\mathrm{Na}_{2} \mathrm{U}_{2} \mathrm{O}_{7}$ & $\mathrm{SEM} / \mathrm{XRD}$ \\
\hline 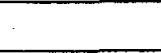 & & & \\
\hline B-110 & $\mathrm{NaNO}_{3}$ & $\mathrm{NP}$ & SEM/XRD \\
\hline B-111 & $\begin{array}{c}\mathrm{Fe}(\mathrm{OH})_{3}(\mathrm{am}) \\
\mathrm{Bi}_{2} \mathrm{O}_{3} \\
\mathrm{Fe}_{2} \mathrm{Bi}\left(\mathrm{SiO}_{4}\right)_{2}(\mathrm{OH})\end{array}$ & $\begin{array}{c}\mathrm{Fe}(\mathrm{OH})_{3}(\mathrm{am}) \\
\mathrm{Bi}_{2} \mathrm{O}_{3} \\
\mathrm{Fe}_{2} \mathrm{Bi}\left(\mathrm{SiO}_{4}\right)_{2}(\mathrm{OH})\end{array}$ & TEM/SEM/XRD \\
\hline C-106 & none & $\begin{array}{c}\mathrm{Fe}(\mathrm{O})(\mathrm{OH}) \\
\mathrm{Ag}_{2} \mathrm{O} \\
\mathrm{ZrO}_{2} \\
\end{array}$ & TEM \\
\hline T-104 & $\begin{array}{c}\mathrm{Fe}_{2} \mathrm{Bi}\left(\mathrm{SiO}_{4}\right)_{2}(\mathrm{OH}) \\
\mathrm{Bi}_{2} \mathrm{O}_{3}\end{array}$ & $\begin{array}{c}\mathrm{Fe}_{2} \mathrm{Bi}\left(\mathrm{SiO}_{4}\right)_{2}(\mathrm{OH}) \\
\mathrm{Bi}_{2} \mathrm{O}_{3} \\
\text { Bismuth Iron Oxide }\end{array}$ & TEM/SEM/XRD \\
\hline $\mathrm{T}-111$ & $\begin{array}{c}\mathrm{Fe}(\mathrm{OH})_{3}(\mathrm{am}) \\
\mathrm{Mn}_{2} \mathrm{MnO}_{4} \\
\mathrm{Fe}_{2} \mathrm{MnO}_{4} \text { (jacobsite) } \\
\mathrm{Fe}(\mathrm{O})(\mathrm{OH}), \text { (goethite) }\end{array}$ & $\begin{array}{c}\mathrm{Fe}(\mathrm{OH})_{3}(\mathrm{am}) \\
\mathrm{Mn}_{2} \mathrm{MnO}_{4} \\
\mathrm{Fe}_{2} \mathrm{MnO}_{4} \text { (jacobsite) } \\
\mathrm{Fe}(\mathrm{O})(\mathrm{OH}), \text { (goethite) }\end{array}$ & TEM/SEM/XRD \\
\hline B-104 & $\mathrm{Na}_{3}\left(\mathrm{NO}_{3}\right)\left(\mathrm{SO}_{4}\right)\left(\mathrm{H}_{2} \mathrm{O}\right)$ (darapskite) & $\begin{array}{c}\mathrm{KMg}_{3}\left(\mathrm{Si}_{3} \mathrm{AlO}\right)-10 \mathrm{H}_{2} \mathrm{O} \\
\text { (phlogopite) }\end{array}$ & XRD \\
\hline TY-104 & $\mathrm{NaNO}_{3}$ (natratine) & none & $\mathrm{XRD}$ \\
\hline SX-113 & none & none & $\mathrm{XRD}$ \\
\hline $\mathrm{C}-104$ & none & none & XRD \\
\hline $\mathrm{C}-105$ & $\mathrm{UO}_{3}\left(\mathrm{H}_{2} \mathrm{O}\right)$ & $\mathrm{Na}_{2} \mathrm{U}_{2} \mathrm{O}_{7}$ & $\mathrm{XRD}$ \\
\hline $\mathrm{AN}-104$ & $\mathrm{UO}_{2}$ or $\mathrm{U}_{3} \mathrm{O}_{7}$ & $\mathrm{UO}_{2}$ or $\mathrm{U}_{3} \mathrm{O}_{7}$ & TEM \\
\hline SY -103 & Fe, Mn oxide & $\mathrm{Fe}, \mathrm{Mn}$ oxide & TEM/SEM/XRD \\
\hline
\end{tabular}


Table 3.4 (continued)

\begin{tabular}{|c|c|c|c|}
\hline Tank & As-Received & Leached & Method \\
\hline & & & \\
\hline AW-105 & none & none & TEM/SEM/XRD \\
\hline SY-101 & none & none & TEM/SEM/XRD \\
\hline & & & SPM \\
\hline$A Z-101$ & $\mathrm{NaNO}_{3}, \mathrm{NaNO}_{2}, \mathrm{Na}_{2} \mathrm{CO}_{3}\left(\mathrm{H}_{2} \mathrm{O}\right)$ & $\mathrm{NP}$ & \\
\hline & & $\mathrm{NP}$ & SEM \\
\hline $\mathrm{AZ}-102$ & $\mathrm{NaNO}_{3}, \mathrm{NaNO}_{2}, \mathrm{Na}_{2} \mathrm{U}_{2} \mathrm{O}_{7}$ & & \\
\hline
\end{tabular}

$\mathrm{NP}=$ measurement not performed, am = amorphous, $\mathrm{c}=$ crystalline 


\subsection{References}

Colton NG, GJ Lumetta, AR Felmy, and JA Franz. 1993. ESPIP Alkaline Tank Sludge Treatment: Fiscal Year 1993 Annual Report, Pacific Northwest Laboratory, Richland, Washington.

Hanlon BM. 2000. Waste Tank Summary Report for Month Ending June 30, 2000. HNF-EP-0182-147, $\mathrm{CH} 2 \mathrm{MHill}$ Hanford Group, Inc., Richland, Washington.

Hill JG, GS Anderson, and BC Simpson. 1995. The Sort on Radioactive Waste Type Model: A Method to Sort Single-Shell Tanks into Characteristic Groups, PNL-9814 Rev. 2, Pacific Northwest Laboratory, Richland, Washington.

Jones EO, NG Colton, GR Bloom, GS Barney, SA Colby, and RG Cowan. 1992. "Pretreatment Process Testing of Hanford Tank Waste for the U.S. Department of Energy's Underground Storage Tank Integrated Demonstration." Proceedings of the International Topical Meeting on Nuclear and Hazardous Waste Management Spectrum '92. American Nuclear Society, Inc., La Grange Park, Illinois 60525.

LaFemina JP. 1995. Tank Waste Treatment Science Task Quarterly Report for April-June 1995, PNL10764, Pacific Northwest Laboratory, Richland, Washington.

Lumetta GJ and JL Swanson. 1993. Pretreatment of Plutonium Finishing Plant (PFP) Sludge: Report for the Period October 1990 - March 1992, PNL-8601, Pacific Northwest Laboratory, Richland, Washington.

Lumetta GJ, BM Rapko, MJ Wagner, J Liu, and YL Chen. 1996a. Washing and Caustic Leaching of Hanford Tank Sludges: Results of FY 1996 Studies, PNNL-11278, Rev. 1, Pacific Northwest National Laboratory, Richland, Washington.

Lumetta, GJ, MJ Wagner, FV Hoopes, and RT Steele. 1996b. Washing and Caustic Leaching of Hanford Tank C-106 Sludge, PNNL-11381, Pacific Northwest National Laboratory, Richland, Washington.

Lumetta GJ, IE Burgeson, MJ Wagner, J Liu, and YL Chen. 1997. Washing and Caustic Leaching of Hanford Tank Sludges: Results of FY 1997 Studies, PNNL-11636, Pacific Northwest National Laboratory, Richland, Washington.

Lumetta GJ, BM Rapko, J Liu, and DJ Temer. 1998. "Enhanced Sludge Washing for Pretreating Hanford Tank Sludges." In Science and Technology for Disposal of Radioactive Tank Wastes, W. W. Schulz and N. J. Lombardo, eds., Plenum Press, New York, pp. 203-218. 
Orme RM, AF Manuel, LW Shelton, and EJ Slaathaug. 1996. Tank Waste Remediation System Privatization Process Technical Baseline, WHC-SD-WM-TI-774, Westinghouse Hanford Company, Richland, Washington.

Rai D, M Sass, and DA Moore. 1987. "Chromium(III) Hydrolysis Constants and Solubility of Chromium(III) Hydroxide," Inorg. Chem., Volume 26, pp. 345-349.

Rapko BM, DL Blanchard, NG Colton, AR Felmy, J Liu, and GJ Lumetta. 1996. The Chemistry of Sludge Washing and Caustic Leaching Processes for Selected Hanford Tank Wastes, PNNL-11089, Pacific Northwest National Laboratory, Richland, Washington.

Temer DJ and R Villarreal. 1995. Sludge Washing and Alkaline Leaching Tests on Actual Hanford Tank Sludge: A Status Report, LAUR-95-2070, Los Alamos National Laboratory, Los Alamos, New Mexico.

Temer DJ and R Villarreal. 1996. Sludge Washing and Alkaline Leaching Tests on Actual Hanford Tank Sludge: FY 1996 Results, LAUR-96-2839, Los Alamos National Laboratory, Los Alamos, New Mexico.

Temer DJ and R Villarreal. 1997. Sludge Washing and Alkaline Leaching Tests on Actual Hanford Tank Sludge: FY 1997 Results, LAUR-97-2889, Los Alamos National Laboratory, Los Alamos, New Mexico.

Wefers K and C Misra. 1987. Oxides and Hydroxides of Aluminum, Alcoa Technical Paper No. 19, Revised. Alcoa Laboratories, Pittsburgh, Pennsylvania. 


\section{Distribution List}

No. of Copies

\section{OFFSITE}

2 DOE Office of Scientific and Technical information

Phil McGinnis

Oak Ridge National Laboratory

P.O. Box 2008

Oak Ridge, Tennessee 37831-6223

Dr. Harry Babad

2540 Cordoba Ct.

Richland, Washington 99352

\section{ONSITE}

1 Numatic Hanford Corporation

R. Kirkbride

R3-73

$3 \mathrm{CH} 2 \mathrm{MH}$ Hill Hanford Group, Inc.
M. E. Johnson
D. A. Reynolds
$\mathrm{H} 4-02$
K. A. Gaspar
R2-11
H4-02

No. of Copies

\section{ONSITE}

2 Fluor Hanford

D. L. Herting

J. C. Person

T6-07

T6-07

3 U.S. Department of EnergyRichland Operations
J. D. Long
K8-50
E. J. Cruz
H6-60
B. M. Mauss
K8-50

21 Pacific Northwest National Laboratory
N. G. Colton
K8-93
G. J. Lumetta (5)
P7-25
B. M. Rapko (5)
P7-25
W. F. Bonner (5)
K9-14
Technical Report Files (5) 